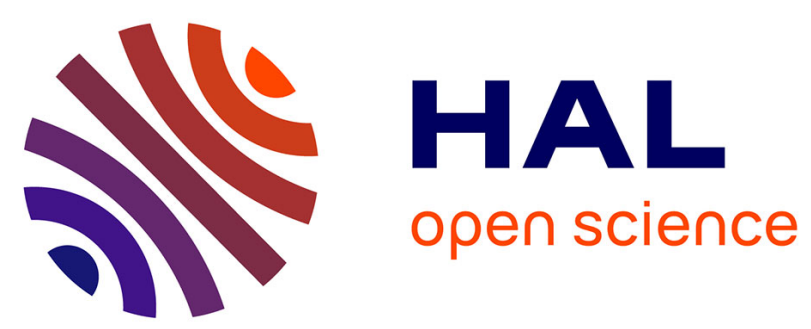

\title{
Impact of pest management practices on the frequency of insecticide resistance alleles in Bemisia tabaci (Hemiptera: Aleyrodidae) populations in three countries of West Africa
}

Olivier Gnankine, Omer Hema, Moussa Namountougou, Laurence Mouton, Fabrice Vavre

\section{To cite this version:}

Olivier Gnankine, Omer Hema, Moussa Namountougou, Laurence Mouton, Fabrice Vavre. Impact of pest management practices on the frequency of insecticide resistance alleles in Bemisia tabaci (Hemiptera: Aleyrodidae) populations in three countries of West Africa. Crop Protection, 2018, 104, pp.86 - 91. 10.1016/j.cropro.2017.10.020 . hal-01916784

\author{
HAL Id: hal-01916784 \\ https://hal.science/hal-01916784
}

Submitted on 10 Jan 2019

HAL is a multi-disciplinary open access archive for the deposit and dissemination of scientific research documents, whether they are published or not. The documents may come from teaching and research institutions in France or abroad, or from public or private research centers.
L'archive ouverte pluridisciplinaire HAL, est destinée au dépôt et à la diffusion de documents scientifiques de niveau recherche, publiés ou non, émanant des établissements d'enseignement et de recherche français ou étrangers, des laboratoires publics ou privés. 
2 Impact of pest management practices on the frequency of insecticide 3 resistance alleles in Bemisia tabaci (Hemiptera: Aleyrodidae) populations in 4 three countries of West Africa.

5

7

8

9

10 (1)

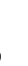

\section{Olivier Gnankiné ${ }^{a}$, Hema Omer ${ }^{b}$, Moussa Namountougou ${ }^{c}$, Laurence Mouton ${ }^{d}$ and} Fabrice Vavre ${ }^{d}$

a Laboratoire d'Entomologie Appliquée, Université de Ouaga I Pr Joseph KI-ZERBO, Burkina Faso.

b Institut de 1'Environnement et de Recherches Agricoles, BP 390 Bobo-Dioulasso, Burkina

Faso

c Université Nazi Boni de Bobo-Dioulasso, Burkina Faso

d Université de Lyon, Université Lyon 1, CNRS, Laboratoire de Biométrie et Biologie

Evolutive UMR5558, F-69622 Villeurbanne, France.

* Corresponding author: Laboratoire d'Entomologie Fondamentale et Appliquée,

Departement de Biologie et Physiologie Animales, Université de Ouagadougou, 03 BP 7021

Ouagadougou 03, Email : olivier.gnankine@univ-ouaga.bf; olgnankine@ hotmail.com

6


ABSTRACT

In West Africa, the use of organophospates and pyrethroids insecticides to control cotton pests has led to the evolution of resistance in field populations of Bemisia tabaci Gennadius. Three pest management programs have been commonly recommended: the Conventional Program (CP) where 6 treatments are applied, the use of $B t$ cotton plants for which only 2 applications of neonicotinoids are required and that has been adopted in many countries, and a biological program (BP) without any chemical treatment. The present study aims to determine the influence of these practices on the frequency of mutations that confer resistance to pyrethroids (mutation L925I in the para-type voltage-gated sodium channel gene) and organophosphates (mutation $\mathrm{F} 331 \mathrm{~W}$ in the acetylcholinesterase enzyme ace 1 : allele Ace $1^{R}$ ) in B. tabaci populations using Bt cotton and CP areas in Pô and Saria (Burkina Faso), CP and BP areas in Kandi (Benin) and only CP areas in Tové and Infa (Togo). All individuals sampled belonged to the MED (biotypes MED-Q1) and Africa Silver Leafing (ASL) species. MED-Q1 was found in sympatry with ASL in Burkina Faso both on CP and Bt cotton areas at variable frequencies. In Togo and Benin, only ASL was found, except in Tové where MEDQ1 was also detected, but at low frequency. Frequencies of mutations that confer resistance varied between localities and species but we did not find any strong evidence of a relationship between the pest management program and these frequencies except for the allele Ace $I^{R}$ in Burkina Faso for which the frequencies decrease when chemical applications are reduced. This study provides valuable information for the development of efficient integrated pest management programs.

Key words: Pest management programs, insecticides, $k d r$, Ace $1^{R}$, Bemisia tabaci. 


\section{Introduction}

In western Africa, cotton is an economically important crop providing substantial incomes for farmers. However, the cotton plant is attacked by key pests including the cotton bollworm, Helicoverpa armigera (Lepidoptera: Noctuidae) and the whitefly Bemisia tabaci Gennadius (Hemiptera: Aleyrodidae). Three main spraying programs are recommended to control these pests in many countries of West Africa. They include the Conventional Cotton program $(\mathrm{CP})$, the Biological Program (BP) and the transgenic Bt cotton program (Bt Cotton). The CP is based on calendar-based applications of insecticides belonging to pyrethroids, organophosphates and neonicotinoids families separately or as a mixture (Gnankiné et al., 2013a; Silvie et al., 2013). They are applied with temporal rotations during the whole cotton season (from May to October). The repeated use of such insecticides have imposed strong selection pressures on target pests' populations, resulting in the evolution of field resistances (Houndeté et al., 2010). Over $\$ 60$ millions of chemicals were spent for chemical pests control in Burkina Faso (Greenplate et al., 2006). The BP relies on the use of biopesticides and natural fertilizers without utilization of any chemical. The $B t$ cotton program uses Bt (Bacillus thuringiensis) transgenic cotton plants that express two crystal toxins (Cry1 Ac and Cry2Ab) that target some major lepidopteran pests but are harmless to vertebrates and most other organisms (Mendelsohn et al., 2003; Sanahuja et al., 2011; Pardo-Lopez et al., 2013). In this program, only neonicotinoids are used at the end of the cotton phenological stages (Héma et al., 2009). It was initiated in 2008 in West Africa but only in Burkina Faso. In 2016, the Burkina Faso government suspended the use of $B t$ technology due to the quality of cotton fiber which is shorter than the fiber of conventional cotton.

One of major threat to cotton plant remains the whitefly B. tabaci. It causes damages directly through phloem feeding and indirectly through the transmission of plant viruses. B. tabaci is a 
complex of cryptic species whose taxonomy is still not entirely resolved. Based on the current consensus, B. tabaci is mostly represented by the MED species in western Africa, even though AnSL species can also be found (Gnankiné et al., 2013b; Gnankiné et al., 2013c). Within the MED species, different biotypes are encountered including MED-Q1, MED-Q3 and ASL. Actually, recent analyses suggest that MED-Q1 and ASL do not hybridize in the field and that ASL is thus a different species (Mouton et al., 2015). Interestingly, these species/biotypes differ in terms of host plants range and insecticide resistance traits. Generally, MED-Q1 is predominant in cotton areas and sometimes found in sympatry with ASL on vegetables crops (Gnankiné et al., 2013b). It is also associated with higher levels of resistance to some insecticides as pyrethroids, organophosphates and neonicotinoids (Gnankiné et al., 2013a). In B. tabaci, two mutations in the para-type voltage-gated sodium channel gene, L925I and T929V, and one mutation in the acetylcholinesterase enzyme acel (F331W: allele Ace $l^{R}$ ) confer resistance to pyrethroids and organophosphates, respectively (Roditakis et al., 2006; Alon et al., 2008; Tsagkarakou et al., 2009). Recent studies showed that the Ace $1^{R}$ was found in both MED-Q1 and ASL but, while this resistant allele was almost fixed in MED-Q1 (0.99), its frequency was 0.59 in ASL (Mouton et al., 2015). In addition, while the L925I mutation in the sodium channel gene is almost fixed in MED-Q1 populations, it is rarely detected in ASL. The T929V was never found in B. tabaci populations from West Africa (Mouton et al., 2015). The objectives of the present study were to perform a first analysis of the impact of the agricultural practices on the B. tabaci biotypes/species composition and diversity, and the frequencies of alleles that confer resistance to pyrethroids and organophosphates. Sampling was performed in three countries of Western Africa: Burkina Faso, Benin and Togo. 


\section{Materials and methods}

114

\subsection{Management of cotton pests}

Three pest control programs are recommended in West African countries:

(i) The Conventional Program (CP) is based on two to four treatments with pyrethroids (PY) plus organophosphates (OP) and 2 other treatments with neonicotinoids (see table 1 for details).

(ii) The Biological control Program (BP) does not use chemicals for plant protection. Farmers worked under the supervision of technicians from the Beninese Organization for Organic Farming Promotion (OBEPAP) who participated in the implementation and the survey of good agricultural practices on organic cotton.

(iii) The transgenic cotton program (Bt Cotton). In this program, pesticides belonging to OP and PYR are not used. Only neonicotinoids are used at boll opening stage to control sucking pests. In this case, farmers worked under the supervision of technicians from societies of textile fibers in Burkina Faso.

\subsection{B. tabaci sampling}

Sampling was performed in october and november between 2009 and 2015 in three countries of Western Africa: Burkina Faso, Benin and Togo (Figure 1, Table 2). In Burkina Faso, whiteflies were collected randomly in two localities, Pô in 2013 and Saria in 2015, from Bt cotton and CP fields. In Pô, Bt cotton represented $90 \%$ of the sampled fields while in Saria it represented 15\%. In Benin, sampling was done at Kandi in 2009 in $\mathrm{CP}$ and BP areas (BP represent around $10 \%$ of areas). In Togo, collection was done randomly in two sites in 2009, Infa and Tové, where only CP is used. The collected adult whiteflies were stored in ethanol 
95\%. The origin of the samples (location) and the number of individuals are summarized in Table 2.

2.3 Molecular analysis

\section{$\underline{\text { DNA extraction }}$}

For each individual, total DNA was extracted in $25 \mu$ of an extraction buffer containing $50 \mathrm{mM} \mathrm{KCl}, 10 \mathrm{mM}$ Tris-base $\mathrm{pH} 8,0.45 \%$ Nonidet P-40, $0.45 \%$ Tween 20 and $50 \mathrm{mg} / \mathrm{ml}$ proteinase $\mathrm{K}$. After $3 \mathrm{~h}$ at $65^{\circ} \mathrm{C}$, samples were incubated at $100^{\circ} \mathrm{C}$ for $15 \mathrm{~min}$. Pure water $(35 \mu \mathrm{l})$ was then added to the extract.

\section{$\underline{\text { Identification of } B \text {. tabaci }}$}

Species/biotypes were identified using the Polymerase Chain Reaction-Random Fragment Length Polymorphism (PCR-RFLP) diagnostic assay based on the mitochondrial cytochrome oxidase 1 gene sequence ( $m+C O 1)$ described in Henri et al. (2013). This technique allows discriminating the species/biotypes present in West Africa (Gnankiné et al., 2013b).

Identification of susceptible and resistant alleles of the sodium channel and the $\underline{\text { acetylcholinesterase ace } 1 \text { genes }}$

Resistant and susceptible alleles in the para-type voltage-gated sodium channel and acel genes were identified using the diagnostic assays developed by Tsagkarakou et al. (2009). Briefly, ace1-susceptible (F331) and -resistant (W331) alleles, as well as susceptible (L925) and resistant (I925) para-type voltage-gated sodium channel alleles were detected using PCRRFLP (Tsagkarakou et al. 2009). Some PCR products were sequenced for each susceptible and resistant allele and each country. We never found the T929V mutation in the sequences. The frequencies of $k d r$ and ace- $1^{R}$ mutations were calculated according to the formula $p=\mathrm{n} \sigma^{\urcorner}(\mathrm{R})+2 \mathrm{n}$ 우 $(\mathrm{RR})+\mathrm{n}$ 우 $(\mathrm{RS}) / \mathrm{n} \sigma^{\urcorner}+2 \mathrm{n}$ 우 where RR was the number of homozygotes, $\mathrm{RS}$ the number of heterozygotes and $\mathrm{n}$ the size of specimens analysed. 
2.4 Statistical analyses

163 Statistical analysis were performed using the $\mathrm{R}$ statistical software (http://www.R-

164 project.org). The effects of the pest management practices on the proportions of $B$. tabaci composition and the frequencies of resistance alleles were tested by using Fisher's exact tests.

\section{Results}

\subsection{Geographic distribution of biotypes}

All the 170 B. tabaci individuals collected in 5 localities in Burkina Faso, Benin and Togo belonged to MED-Q1 or ASL (Table 2). In Togo and Benin, only ASL was found (except one MED-Q1 individual in Tové), while in Burkina Faso, MED-Q1 and ASL were found in sympatry at variable frequencies: depending on the locality, it was either ASL or MED-Q1 that predominated. In Pô, the frequency of ASL reached more than $80 \%$ whatever the control strategy (CP or Cotton Bt). In Saria, MED-Q1 was more common than ASL, but their relative frequencies depended on the management program: on $\mathrm{CP}$ areas, $93 \%$ of individuals belonged to MED-Q1 while only 57\% of whiteflies were MED-Q1 on Bt Cotton fields (Fisher exact test, $\mathrm{p}<0.005$ ).

\subsection{Frequency of the L925I mutation}

For the para-type voltage-gated sodium channel gene, we studied the frequency of the L925I mutation that correspond to the allele called r1 by Alon et al. (2008). We found high variations depending on the country (Fisher exact test, $\mathrm{p}<0.0005)$. Indeed, in Burkina Faso, r1 
was fixed for both MED-Q1 and ASL in the two localities (Table 3). In Benin, this allele has not been found (Table 4). In Togo, its frequency varied between 0.5 and 0.75 (Table 5).

\subsection{Frequency of the Ace- $1^{R}$ allele}

For the acetylcholinesterase gene, we studied the presence of the F331W mutation (R allele). Globally, the frequency of this allele was more homogeneous among countries than for the L925I mutation and ranged between 0.71 and 1 (Fisher exact test, $\mathrm{p}=0.08$ ). In Togo, this frequency did not differ between the two localities, Infa and Tové (Table 5; Fisher exact test, $\mathrm{p}=0.1$ ). In Benin, where sampling was performed in only one locality, the frequency of $\mathrm{R}$ varied between 0.7 and 0.9 but did not significantly differ between the fields that were treated either with BP or CP program (Table 4; Fisher exact test, $\mathrm{p}=0.49$ ).

In Burkina Faso, the frequency of the resistant allele changed in the two localities according to the treatment: it was lower in Bt Cotton areas than in CP fields (Table 3; Fisher exact test, $\mathrm{p}=0.003$ for Pô and $\mathrm{p}<0.0005$ for Saria). In the two localities, $\mathrm{R}$ was fixed in MED-Q1 in the $\mathrm{CP}$ fields while it had a frequency of 0.5 and 0.875 in Pô and Saria respectively in $B t$ areas (Fisher exact test, $\mathrm{p}<0.0005$ ). For ASL, differences were not so important and not statistically significant (Fisher exact test, $\mathrm{p}>0.05$ ) with a range of frequencies between 0.91 and 1 for CP fields and $0.71-0.83$ for $B t$ cotton fields. 


\section{Discussion}

In this paper, we present the distribution of $B$. tabaci biotypes/species and the frequencies of the mutations in the para sodium channel gene $(k d r)$ and in the Acetylcholinesterase gene $\left(\right.$ ace $\left.-1^{R}\right)$ associated with resistance to Pyrethroids and Organophosphates respectively of the pest B. tabaci in 3 countries of Western Africa in connection with the pest management programs.

Our results confirmed the diversity of $B$. tabaci biotypes on cotton in these countries. As previously described by Gueguen et al. (2010) and Gnankiné et al. (2013b), MED-Q1 and ASL were detected in Burkina Faso, frequently in the same areas. Despite this sympatry, population genetics analyses on microsatellite markers suggested that MED-Q1 and ASL do not hybridize in the field (Mouton et al. 2015). It was also showed that they do not share insecticide resistance alleles. ASL previously classified in MED-species might thus be considered now as putative species (Mouton et al. 2015).

In the current study, the L925I mutation was fixed in MED-Q1 and ASL individuals in Burkina Faso. Regarding ASL, this is in sharp contrast with the situation observed in 2009 and 2010, as this mutation only reached 0.02 at that time in the western part of Burkina Faso (Mouton et al. 2015). This is also in contrast with the situation found in Benin, where this resistant allele was not found, whatever the control program. Finally, the situation is intermediate in Togo where the frequencies varied between 0.5-0.75 in $\mathrm{CP}$ or $\mathrm{BP}$ programs. The fixation of this L925I mutation might be explained by a high selection pressure due to the repetitive pyrethroids treatments applied in western Africa particularly on cotton and vegetables (Gnankiné et al., 2007; Ahouangninou et al., 2011; Gnankiné et al. 2013b).

The management of the resistance mutations in the para-type voltage-gated sodium channel gene, L925I but also T929V, seems to be difficult as they prove to be persistent even without 
selection in laboratory, suggesting a low fitness cost (Roditakis et al., 2006). This low fitness cost was confirmed by Alon et al. (2006) where no departures from Hardy-Weinberg equilibrium were observed when the frequency of resistant genotypes was investigated in $B$. tabaci populations reared without any insecticide selection for many years. Accordingly, we could not detect any impact of the control program on the frequency of these resistance mutations.

For the F331W mutation (acel gene), the frequencies of resistant alleles were very variable. According to Mouton et al. (2015), the frequencies of the F331W mutation in the ace 1 gene in individuals from Burkina Faso were 0.98 and 0.59 for MED-Q1 and ASL, respectively. Our data indicated that the frequency of resistance may be lower in individuals sampled in fields using $B t$ cotton strategy than in the fields using $\mathrm{CP}$. This effect was more pronounced in MED-Q1 than ASL, and also more pronounced in Pô than in Saria. The high frequencies observed in Saria could be due to the number of applications done for the pest control. Indeed, near Saria, many farmers cultivate vegetables that are systematically treated with pyrethroids and Organophosphates. On the contrary, in Pô, no vegetables were cultivated and the insecticide pressure was low. Moreover, a drastic lack of resistant homozygous in the $B t$ cotton fields is consistent with the hypothesis of a high fitness cost associated with the F331W mutation in this species. As $90 \%$ of the zone was using Bt in Pô, while it was only $15 \%$ in Saria, the refuge zone without treatment is thus much more important in Pô, which could allow a more rapid counter-selection of resistance alleles without treatment. On the other hand, we could not detect any effect of the control program in Benin (CP vs. BP). This may be explained by the fact that only $10 \%$ of the surface were cultivated using BP program. In Togo, we did not detect any significant difference in the mutation frequencies in the two areas but they were under the same insecticide pressure. 
272 Other mechanisms of insecticide resistance, like metabolic resistance may be associated to

273 high frequencies of the two mutations in individuals insects conferring a multiple resistance.

274 Indeed, detoxifying enzymes such as esterases, glutathione S-transferases, and cytochrome

275 P450-dependent monooxygenases are involved in resistance to numerous insecticide classes

276 (Alon et al., 2008; Rauch and Nauen , 2003; Ma W et al., 2010).

277 In conclusion, our results suggest that different control programs may alter the frequency of

278 resistance alleles. However, the counter-selection of resistance alleles may depend on the one

279 hand on the fitness cost associated with resistance, and the other hand to the relative surface

280 of untreated areas. This clearly advocates for a better integration of control measures against

281 B. tabaci across the different host crops.

282

283

284

285

286

287

288

289 290

291

292

293

294

\section{8} 89

\section{Acknowledgments}

The authors are grateful to the following institute for the samples collection and the technical assistance from Inera and University of Lomé. 


\section{References}

299

300

301

302

303

304

305

306

307

308

309

310

311

312

Ahouangninou C, F.B. and M.T., 2011. Évaluation des risques sanitaires et environnementaux des pratiques phytosanitaires des producteurs maraîchers dans la commune rurale de Tori-Bossito (Sud-Bénin). Cah. Agric. 20, 216-222.

Alon, M., Alon, F., Nauen, R., Morin, S., 2008. Organophosphates' resistance in the Bbiotype of Bemisia tabaci ( Hemiptera : Aleyrodidae) is associated with a point mutation in an ace1 -type acetylcholinesterase and overexpression of carboxylesterase 38, 940949. doi:10.1016/j.ibmb.2008.07.007

Alon, M., Benting, J., Lueke, B., Ponge, T., Alon, F., Morin, S., 2006. Multiple origins of pyrethroid resistance in sympatric biotypes of Bemisia tabaci (Hemiptera: Aleyrodidae). Insect Biochem. Mol. Biol. 36, 71-79. doi:10.1016/j.ibmb.2005.10.007

Gnankiné, O., Bassolé, I.H.N., Chandre, F., Glitho, I., Akogbeto, M., Dabiré, R.K., Martin, T., 2013a. Insecticide resistance in Bemisia tabaci Gennadius (Homoptera: Aleyrodidae) and Anopheles gambiae Giles (Diptera: Culicidae) could compromise the sustainability of malaria vector control strategies in West Africa. Acta Trop. 128. doi:10.1016/j.actatropica.2013.06.004

Gnankiné, O., Mouton, L., Henri, H., Terraz, G., Houndeté, T., Martin, T., Vavre, F., Fleury, F., 2013b. Distribution of Bemisia tabaci (Homoptera: Aleyrodidae) biotypes and their associated symbiotic bacteria on host plants in West Africa. Insect Conserv. Divers. 6. doi:10.1111/j.1752-4598.2012.00206.x

Gnankiné, O., Mouton, L., Savadogo, A., Martin, T., Sanon, A., Dabire, R.K., Vavre, F., Fleury, F., 2013c. Biotype status and resistance to neonicotinoids and carbosulfan in Bemisia tabaci (Hemiptera: Aleyrodidae) in Burkina Faso, West Africa. Int. J. Pest Manag. 59. doi:10.1080/09670874.2013.771806 
Gnankiné, O., Traoré, D., Sanon, A., Traoré, N.S. \& Ouedraogo, A.P., 2007. Traitements insecticides et dynamique des populations de Bemisia tabaci Gennadius en culture cotonnière au Burkina Faso. Cah. Agric. 16.

Gueguen, G., Vavre, F., Gnankine, O., Peterschmitt, M., Charif, D., Chiel, E., Gottlieb, Y., Ghanim, M., Zchori-Fein, E., Fleury, F., 2010. Endosymbiont metacommunities, mtDNA diversity and the evolution of the Bemisia tabaci (Hemiptera: Aleyrodidae) species complex. Mol. Ecol. 19, 4365-4376. doi:10.1111/j.1365-294X.2010.04775.x

Héma, O., Somé, H.N., Traoré, O., Greenplate, J., Abdennadher, M., 2009. Efficacy of transgenic cotton plant containing the Cry1 Ac and Cry2Ab genes of Bacillus thuringiensis against Helicoverpa armigera and Syllepte derogata in cotton cultivation in Burkina Faso. Crop Prot. 28, 205-214. doi:10.1016/j.cropro.2008.09.014

Henri, H., Terraz, G., Gnankiné, O., Fleury, F., Mouton, L., 2013. Molecular characterization of genetic diversity within the Africa/Middle East/Asia Minor and Sub-Saharan African groups of the Bemisia tabaci species complex. Int. J. pest Manag. 59, 329-338. doi:10.1080/09670874.2013.869374

Houndeté, T. A., Kétoh, G.K., Hema, O.S. a, Brévault, T., Glitho, I. A., Martin, T., 2010. Insecticide resistance in field populations of Bemisia tabaci (Hemiptera: Aleyrodidae) in West Africa. Pest Manag. Sci. 66, 1181-1185. doi:10.1002/ps.2008

Ma W, Li X, Dennehy TJ, Lei C, Wang M, D.B. and N.R., 2010. Pyriproxyfen resistance of Bemisia tabaci (Homoptera: Aleyrodidae) biotype B: metabolic mechanism. J. Econ Entomol 103, 158-165.

Mike Mendelsohn, Kough1, J., Vaituzis, Z., Keith, M., 2003. Are Bt crops safe? Nat. Biotechnol. 21, 1003-1009. doi:10.1038/nbt0903-1003

Mouton, L., Gnankiné, O., Henri, H., Terraz, G., Ketoh, G., Martin, T., Fleury, F., Vavre, F., 2015. Detection of genetically isolated entities within the Mediterranean species of Bemisia tabaci: New insights into the systematics of this worldwide pest. Pest Manag. Sci. 71. doi:10.1002/ps.3834 
Pardo-Lopez, L., Soberon, M., Bravo Alejandra, 2013. Bacillus thuringiensis insecticidal three-domain Cry toxins: mode of action, insect resistance and consequences for crop protection. FEMS, Microbiol. Rev. 37, 3-22. doi:10.1111/j.1574-6976.2012.00341.x

Rauch N and Nauen R, I. (2003)., 2003. Identification of biochemical markers linked to neonicotinoid cross resistance in Bemisia tabaci (Hemiptera: Aleyrodidae). Arch Insect Biochem Physiol 54, 165-176.

Roditakis, E., Tsagkarakou, A., Vontas, J., 2006. Identification of mutations in the para sodium channel of Bemisia tabaci from Crete, associated with resistance to pyrethroids. Pestic. Biochem. Physiol. 85, 161-166. doi:10.1016/j.pestbp.2005.11.007

Sanahuja, G., Banakar, R., Twyman, R.M., Capell, T., Christou, P., 2011. Bacillus thuringiensis : a century of research, development and commercial applications 283300. doi:10.1111/j.1467-7652.2011.00595.x

Silvie, J.P., Renou, A., Vodounnon, S., Bonni, G., Obayomi, M., Héma, O., Prudent, P., Sorèze, J., Ochou, G., Togola, M., 2013. Threshold-based interventions for cotton pest control in West Africa: What's up 10 years later ? Crop Prot. 43, 157-165.

Tsagkarakou, A., Nikou, D., Roditakis, E., Sharvit, M., Morin, S., Vontas, J., 2009. Molecular diagnostics for detecting pyrethroid and organophosphate resistance mutations in the $\mathrm{Q}$ biotype of the whitefly Bemisia tabaci (Hemiptera: Aleyrodidae). Pestic. Biochem. Physiol. 94, 49-54. doi:10.1016/j.pestbp.2009.03.002

Vitale, J., Glick, H., Greenplate, J., 2006. The Economic Impacts of Monsanto's Paper, Bollgard II in West Africa: Emprirical Evidence from Burkina Faso, in: 10th ICABR Conference, Ravello, Italy. 